\title{
木材繊維の形態的特性と紙の性質について
}

\author{
山陽パルプ株式会社総合研究所 守屋 正夫
}

\section{Characteristics of Papers and the Morphological Properties of Woods}

\author{
Masao Moriya \\ (Sanyo Pulp Co., Ltd. General Research Laboratory)
}

The weight volume of wood, WRV of pulp and certain physical properties of paper of some tropical and Japanese hardwoods were studied from the morphological point of view.

Correlation between the ratio of lumen diameter and fiber diameter $(l / D)$ was found to have close relationship to such properties as the weight volume of wood, the water retention value of pulp, the bulk density, stiffness, burst factor, breaking length, folding number and air permeability of paper. And the correlation between the ratio of fiber length and fiber diameter $(L / D)$ and the tear factor of paper was revealed.

Thus it may be possible to estimate the quality of pulpwoods and to improve the characteristics of papers by making use of these fiber dimension ratios as indices.

\section{要旨}

南方産広葉樹ならでに日本産広葉樹を対象に選ご， 擮維の形態的特性と,木材の容積重, パルプの保水性尔 こび紙葉の強度的特性との関係について検討を行なっ た。その結果繊維ディメンションの組み合せ比, 特に ルーメン幅/繊維幅の比 $(\bar{l} / \bar{D})$ :, 木材の容積重, パ ルプの保水性, 紙の緊度, 剛度, 力比, 裂断長, 耐折 芰，透気度などさ相関関係が成立する。李心繊維長/ 渽維幅の比 $(\bar{L} / \bar{D})$ 以比引裂き度之相関関係ぶ得られ る。往ってこれらの繊維ディメンション比を指標にし て，パルプ原木の品質の評洒ならごに紙葉の品筫を改 善するための手掛りを得るここが可能となうう。

\section{I 緒}

\section{言}

一般に紙の特性洼えれを構成する原料パルプつ浂態 的あるいは化学的性質によって，色々な影響をうける。 そのため影響の程度や本質については, 過去幾多の研 究者により研究され，秀心今日もな扮研究課題に取り 亦げられている。例完ば影響を及ぼす要因として，へ ミセルロースの量ならごに種類, リグニン量, 各成分 つ分布状態, 重合度, 単繊維強度, 膨潤性, 乾燥に上 る角質化, 纎維の長短, 細胞膜の厚さ, フィブリル角, 㐫るいはこれら要因の相互作用など，多くの因子が考 えられる。紙の性質に対する繊維の形態的特性の重要 さについては, Tappi Forest Biology Committee(1) でも述ベられているが，従来紙の強度については，主 として繊維の長さと関連があり，長繊維をふくむパル
プは，良質の紙を诰るで峁ろらといら一般的な概念に 左右されていた。しふし, Peteri ${ }^{(2)}$ は, アフリカの Dacryodes Klaineana が短繊維からなるにるかかわ らず，これを原料之する紙は充分な強度を持っている ことを示した，今村 ${ }^{(3)}, H_{\text {olzer }}{ }^{(4)}$ らは原木呫春材と 夏材を分離し，これらを別々にパルプ化して両者の特 性を比較した。それによると夏材からのパルプは，春 材に比べて難吒解性である。また夏材パルプから作っ た紙は高い引裂学強度をもっているが，忌圈りや破裂 強さは低く, 多孔性でかさ高い紙を作る。一方春材パ ルプから作った紙は吒解によって紙力が六寻く向上し， 引張りや破裂強さ浩高く, 引裂さ強出注任、方, 緻密 で地合のよい紙を作ることを認めている。可他原木 の繊維組成之紙力の関係について裂断長之力比は, 夏 材の割合に逆比例するといら見解も示されている(5 7)。

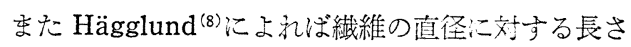
の比は，紙の強度に重要な影響を及ぼすしのべている。 Runkel ${ }^{(9)}$ らは広葉樹から作られたパルプの製紙性質 について検討を行ない。一般に繊維膜つ厚さ之内腔の 直径との関係, すなわ台 $2 W / l$ (ここであは繊維膜 の厚さ, $l$ はルーメンの幅）の比が 1 より六当い場合 には，製紙のなめに法適当でなく，1より小さい繊維 が製紙原料として，良好であることを認めている。さ らに Watson ${ }^{10)}$ らは繊維の幅とルーメンの輻つ比が, 紙の性質に関係があるとのべている。京た Dinwoo$\mathrm{die}^{(11)}$ は紙の性質と木材繊維の化学的空よび形態的特 性との関係について, 最近に至るまでの主な文献を照 会しているが, いづれる瀻維長単独では, 紙質に寄与 
する絾維の重要な特性を, 充分表わし得ないことを認 めておう，その他の繊維の形態的特性，すなわち繊維 幅, ルーメン幅, 繊維膜厚などの果たす役割について の認識が高弯ってきている ${ }^{(12 \sim 16)}$ 。

本研究で沽南方産ならびに日本産の色々な広葉樹の 繊維の繊維長, 繊維幅, ルーメン幅, 繊維膜厚のよう な緎維の形態的特性が，クラフトパルプより作った紙 の性質に就よ゙ず影響を検討するため，特に各瀻維の ディメンションの組み合せを選択し，これらの因子と 原木ならごて紙の性質との関連性を求めた。

\section{II 供試材および実験方法}

\section{1. 供 試 材}

南方材として 28 種類の広葉樹をフィリップンから 入手した。こ礼らのうち大部分は，ふたばがき科に属 するものであるが，その他に，乙なのき科，かきのき 科，きううちくうう科，ふと之科などに属するものも ある(17)。事た樹種名は学名のくわしくないものも市 るため，地方名をそのまま用いた。日本産材は主とし て本邦西部地区の九州，四国，中国地方から集めた広 葉樹を対象にした。

\section{2. 実 験 方 法}

容積重, 䋐維長, 木材分析—-Tappi Standard 法 を準用した。

保水性一一各樹種より Wise 法によりホロセルロー スを調製し Jayme ${ }^{(18)} ら の$ 方法を準用した。すなわち 繊維構造の影響をより拡大するため，水の代りに水よ り膨潤能力の大きい $17.5 \%$ カ性ソーダ液に浸漬した後, 1,000G で 10 分間遠心分離を行ない絶乾パルプ重量に 対する膨潤パルプ重量の比を求め保水性として示した。 蒸解条件一内容 $5 l$ のステンレス製オートクレーブ を使用し，標隼的サルフェート法蒸解条件として，最 高温度 $165^{\circ} \mathrm{C}$, 最高温度保持時間 1.5 時間, 薬品添加 $20 \%$, 硫化度 $25 \%$ ，液化 4.0 で蒸解した。漂白条件一 一漂白塩素一アルカリーカルシュウムハイポーアル カリ一二酸化塩素の 5 段漂白觉行なった。紙質試験一 一唒パルプを用い JIS 法に従いボールミルで吅解した 後, 手抄总シートを作门濾水度 $210 \mathrm{cc}$, 坪量 $60 \mathrm{~g} / \mathrm{m}^{2}$ の諸強度を求河た。

纎維ディメンション一一木材分析ならびに蒸解用チ ップを採取した部位に近接した所より1枚の円板を切 り取り, 䯣から外部に向って 6 ケの $1 \mathrm{~cm}$ 角のブロッ クを作り，こ礼を水で充分惹沸した後，酶酸，過酸化 水素, 水 (15：20：20）の組成からなる軟化液に室温 で数日間浸清し軟化する。次にこの軟化したブロック を水洗した後，パラフィンで包埋し厚さ $16 \mu$ 前後の薄
い横断切片を作り，エタノール，キシンンの順に切片 を浸漬して切片からパラフインを除いた後，マラカイ トグリンで染色し，カナダバルサムで封入してプレパ ラートを作る。各ブロックより作ったプレパラートよ り拡大倍率 500 倍の写真を作り，瀻維幅ならびにルー メン幅は切線方向に対して測り，また纎維膜厚は半径 方向についてそれぞれ 1,000 本の繊維を測り平均值を 求めた。従って測定した繊維幅, ルーメン幅, 瀻維膜 厚は生材乞のままではないが，纎維に対して膨潤力の 弱いエタノールやキシレンなぞの透徽剤を用いたので, 繊維細胞は膨潤収縮などの大きな変形を受けていない もの之思う。

\section{III 実験結果および考察}

\section{1. 緎維ディメンションと木材および紙の性質との ? 関係}

第 1 ～2 表には南方産ならびに日本産の広葉樹の容 積重, パプ品質, 紙質, 瀻維ディメンションの概要 を示した。次にこれらの数值を基にし木材ならびに紙 の性質と繊維の形態的特性との関連性について検討し てみた。

その結果それぞれの木材ならびにそれを原料として， 作った紙の性質は，各樹種について測定した個々の織 維ディメンションをそのまま用いて検討するよりも， 緎維構造に関連のある纎維の幅, 膜厚およびルーメン

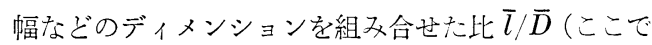
$\bar{l}$ は平均ルーメン幅， $\bar{D}$ :平均瀻維幅を示す。）に上 って示寸方がより関連性が大きいことを認めた。しか し引裂き強度については, 瀻維幅に対する瀻維長の比 $\bar{L} / \bar{D}$ (ここで $\bar{L}$ は平均繊維長， $\bar{D}$ は平均繊維幅を示 す。）の組文合せの方が関連性が大きかった。そと仙 め繊維特性と各原木ならごこ紙の品質特性について, 次の上うな因子間の相関と回帰を求めた。すなお台 $X=$ ルーメン幅/繊維幅 $\bar{l} / \bar{L}$ に対してそれぞれ $Y=$ 容 積重, 保水性, 祭度, 剛度, 力比, 裂断長, 耐折度, 透気度, また $X=$ 繊維長/繊維幅 $\bar{L} / \bar{D}$ に対して $Y=$ 比 引裂き度を設定した。ままたさらに紙質とペントザン量 など化学的成分之の関係汇ついても調べたが，あまり 明確な関連性は得られなかった。

\section{2. ルーメン幅/繊維幅 $\bar{l} / \bar{D}$ と容皘重間の関係}

第 1，2図には南方産ならびに日本産広葉樹の繊維 ディメンション比 $\bar{l} / \bar{D}$ と容積重間の関倸を示した。 南方産広葉樹，日本産広葉樹いづれの場合でも，原木 の容積重が増加すると, 纎維ディメンションの比 $\bar{l} / \bar{D}$ が小さくなる。すなわち厚木はルーメン幅がせまく瀻 維膜厚の厚い繊維から構成されるようになり，材質は 
第 1 表 擜方産広葉樹の容積重, 繊維長, 紙質おっび繊維ディメンション

\begin{tabular}{|c|c|c|c|c|c|c|c|c|c|c|c|c|c|c|c|c|c|}
\hline & \multirow{2}{*}{$\begin{array}{l}\text { 直 径 } \\
(\mathrm{cm})\end{array}$} & \multirow{2}{*}{$\begin{array}{l}\text { 容積重 } \\
(\mathrm{g} / \\
\left.\mathrm{cm}^{3}\right) \\
\end{array}$} & \multirow{2}{*}{$\begin{array}{l}\text { 䋐維長 } \\
(\mathrm{mm})\end{array}$} & \multicolumn{2}{|c|}{ 晒パルプ } & \multirow{2}{*}{$\begin{array}{l}\text { 緊 度 } \\
(\mathrm{g} / \\
\left.\mathrm{cm}^{3}\right)\end{array}$} & \multirow{2}{*}{$\begin{array}{l}\text { 用 度 } \\
(\mathrm{g} \cdot \mathrm{cm})\end{array}$} & \multirow{2}{*}{ 力 比 } & \multirow{2}{*}{$\begin{array}{l}\text { 裂断 } \\
\text { 严 } \\
(\mathrm{km}) \\
\end{array}$} & \multirow{2}{*}{$\begin{array}{c}\text { 耐折度 } \\
\text { (回) }\end{array}$} & \multirow{2}{*}{$\begin{array}{l}\text { 透気度 } \\
\text { (sec) }\end{array}$} & \multirow{2}{*}{ 皆 } & \multirow{2}{*}{$\begin{array}{c}\text { 䋐維幅 } \\
(\mu) \\
(\mu)\end{array}$} & \multirow{2}{*}{$\begin{array}{l}\text { Nーメ } \\
\text { V幅 } \\
(\mu)\end{array}$} & \multirow{2}{*}{ 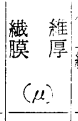 } & \multirow{2}{*}{ 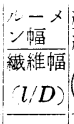 } & \multirow{2}{*}{ 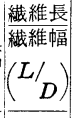 } \\
\hline & & & & $\begin{array}{l}\text { 白色度 } \\
(\%)\end{array}$ & & & & & & & & & & & & & \\
\hline Anabiong & 24 & 0.29 & 1.4 & 85.1 & 9.1 & 0.82 & 0.66 & 5.9 & 8.4 & 2,754 & 1,092 & 73 & 28 & 23.2 & 2.4 & 0.83 & 50.0 \\
\hline Apitong & 11 & 0.58 & 1.8 & 85.3 & 9.0 & 0.67 & 0.74 & 4.4 & 6.4 & 300 & 32 & 150 & 17 & 9.0 & 4.0 & 0.53 & 105.9 \\
\hline Arek (Lohtob) & 27 & 0.30 & 1.2 & 86.3 & 6.8 & 0.81 & 0.69 & 5.7 & 8.2 & 1,880 & 1,379 & 76 & 33 & 27.0 & 3.0 & 0.82 & 36.4 \\
\hline Bacnotan & 27 & 0.32 & 2.1 & 86.7 & 9.0 & 0.71 & 0.66 & 4.7 & 6.9 & 590 & 259 & 116 & 23 & 16.4 & 3.3 & 0.71 & 91.3 \\
\hline Balobo & 28 & 0.60 & 1.8 & 89.1 & 6.2 & 0.71 & 0.80 & 4.5 & 6.2 & 194 & 33 & 129 & 15 & 7.0 & 4.0 & 0.47 & 120.0 \\
\hline Balococ & 26 & 0.46 & 1.8 & 64.7 & 7.4 & 0.71 & 0.76 & 5.3 & 7.3 & 400 & 67 & 110 & 15 & 11.0 & 2.0 & 0.73 & 120.0 \\
\hline Balungay & 24 & 0.83 & 1.0 & 74.8 & 7.7 & 0.62 & 0.94 & 3.0 & 6.0 & 75 & 54 & 95 & 15 & 4.2 & 5.4 & 0.28 & 66.7 \\
\hline Bolong-etang Puti & 29 & 0.63 & 1.4 & 87.9 & 7.6 & 0.66 & 0.72 & 4.0 & 6.0 & 250 & 19 & 113 & 15 & 6.0 & 4.5 & 0.40 & 93.3 \\
\hline Bulong-eta & 24 & 0.68 & 1.1 & 86.8 & 8.8 & 0.69 & 0.70 & 4.2 & 6.2 & 135 & 18 & 117 & 12 & 6.4 & 2.8 & 0.53 & 91.7 \\
\hline Cabitong & 27 & 0.62 & 2.0 & 84.5 & 8.5 & 0.66 & 0.74 & 3.8 & 6.0 & 120 & 27 & 112 & 30 & 20.0 & 5.0 & 0.67 & 66.7 \\
\hline Cele-cele & 23 & 0.63 & 1.6 & 80.0 & 10.1 & 0.66 & 0.80 & 3.2 & 5.0 & 135 & 21 & 123 & 20 & 9.0 & 5.5 & 0.45 & 80.0 \\
\hline Gubas & 22 & 0.32 & 2.6 & 85.2 & 9.1 & 0.75 & 0.66 & 4.8 & 7.0 & 1,030 & 800 & 88 & 35 & 29.4 & 2.8 & 0.84 & 74.3 \\
\hline Kämatög & 33 & 0.51 & 0.9 & 87.2 & 7.3 & 0.71 & 0.76 & 4.8 & 7.4 & 350 & 54 & 94 & 22 & 15.6 & 3.2 & 0.71 & 40.9 \\
\hline Lanete & 25 & 0.49 & 2.2 & 86.7 & 8.0 & 0.60 & 0.66 & 2.4 & 4.1 & 90 & 40 & 96 & 23 & 3.0 & 10.0 & 0.13 & 95.7 \\
\hline Makaasim & 30 & 0.43 & 2.6 & 86.0 & 7.2 & 0.66 & 0.72 & 4.1 & 5.8 & 270 & 45 & 133 & 35 & 22.0 & 6.5 & 0.63 & 74.3 \\
\hline Malaboyog & 30 & 0.61 & 1.5 & 86.2 & 8.9 & 0.76 & 0.72 & 4.4 & 6.5 & 240 & 110 & 114 & 13 & 6.8 & 3.1 & 0.52 & 115.4 \\
\hline Malaikmo & 26 & 0.72 & 2.6 & 66.7 & 8.1 & 0.59 & 0.85 & 3.0 & 5.1 & 156 & 17 & 159 & 18 & 2.8 & 7.6 & 0.16 & 144.4 \\
\hline Malaruhat & 27 & 0.71 & 2.3 & 84.1 & 12.7 & 0.65 & 0.76 & 4.0 & 5.6 & 308 & 38 & 150 & 18 & 6.0 & 6.0 & 0.33 & 127.8 \\
\hline Mänggächapui & 23 & 0.65 & 1.2 & 86.7 & 12.5 & 0.65 & 0.84 & 3.5 & 5.4 & 105 & 17 & 114 & 17 & 5.4 & 5.8 & 0.32 & 70.6 \\
\hline Margapalo & 24 & 0.58 & 1.8 & 85.3 & 11.1 & 0.64 & 0.79 & 3.8 & 5.5 & 160 & 35 & 126 & 23 & 13.0 & 5.0 & 0.57 & 78.3 \\
\hline Mayapis & 27 & 0.38 & 1.8 & 84.0 & 9.9 & 0.75 & 0.73 & 4.5 & 7.0 & 430 & 98 & 122 & 20 & 13.6 & 3.2 & 0.68 & 90.0 \\
\hline Pahutan & 29 & 0.53 & 1.4 & 88.6 & 6.9 & 0.74 & 0.71 & 5.0 & 7.3 & 330 & 31 & 92 & 18 & 14.0 & 2.0 & 0.78 & 77.8 \\
\hline Palc-palac & 24 & 0.46 & 2.0 & 81.9 & 6.1 & 0.68 & 0.71 & 3.3 & 5.4 & 180 & 219 & 118 & 20 & 10.8 & 4.6 & 0.54 & 100.0 \\
\hline Red lauan & 30 & 0.44 & 2.0 & 84.7 & 8.6 & 0.74 & 0.67 & 4.5 & 6.5 & 390 & 101 & 114 & 22 & 16.4 & 2.8 & 0.75 & 90.9 \\
\hline Red nato & 22 & 0.84 & 1.1 & 76.3 & 8.3 & 0.63 & 0.90 & 3.1 & 5.1 & 15 & 7 & 106 & 14 & 4.8 & 4.6 & 0.34 & 78.6 \\
\hline Supa & 25 & 0.63 & 1.5 & 81.9 & 10.0 & 0.72 & 0.82 & 4.9 & 7.3 & 320 & 39 & 98 & 17 & 10.2 & 3.4 & 0.60 & 88.2 \\
\hline Tängile & 24 & 0.40 & 1.6 & 85.5 & 9.3 & 0.70 & 0.81 & 4.5 & 6.7 & 310 & 43 & 122 & 27 & 16.2 & 5.4 & 0.60 & 59.3 \\
\hline White lauan & 23 & 0.44 & 1.3 & 88.1 & 9.4 & 0.77 & 0.72 & 5.5 & 7.5 & 630 & 77 & 102 & 19 & 16.0 & 1.5 & 0.84 & 68.4 \\
\hline
\end{tabular}

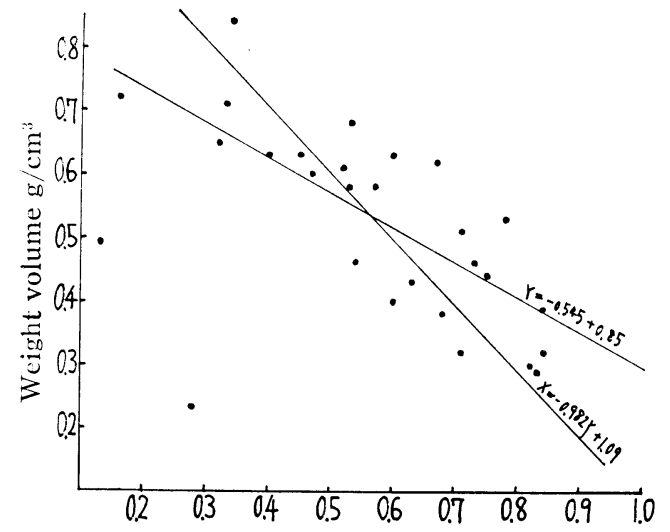

Lumen diameter/Fiber diameter $(\bar{l} / D)$

Fig. 1 Correlation between the weight volume of tropical hardwoods and the ratio of lumen diameter to fiber diameter.

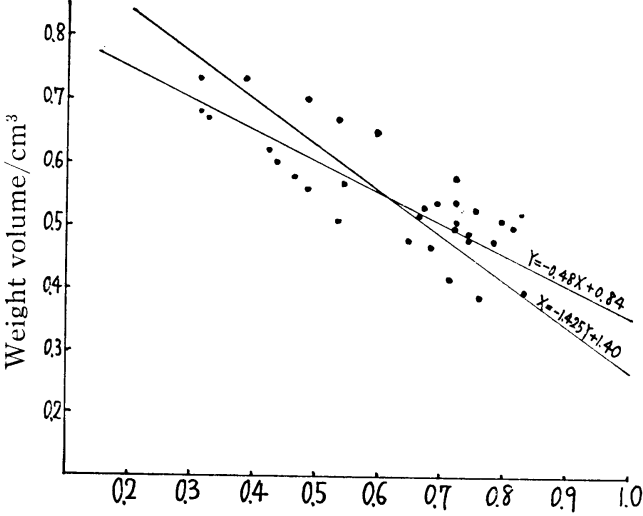

Lumen diameter/Fiber diameter $(\bar{l} / D)$

Fig. 2 Correlation between the weight volume of Japanese hardwoods and the ratio of lumen diameter to fiber diameter. 
第 2 表 日本産広葉樹の容積重, 緎維長, 保水性, 紙質, および繊維ディメンション

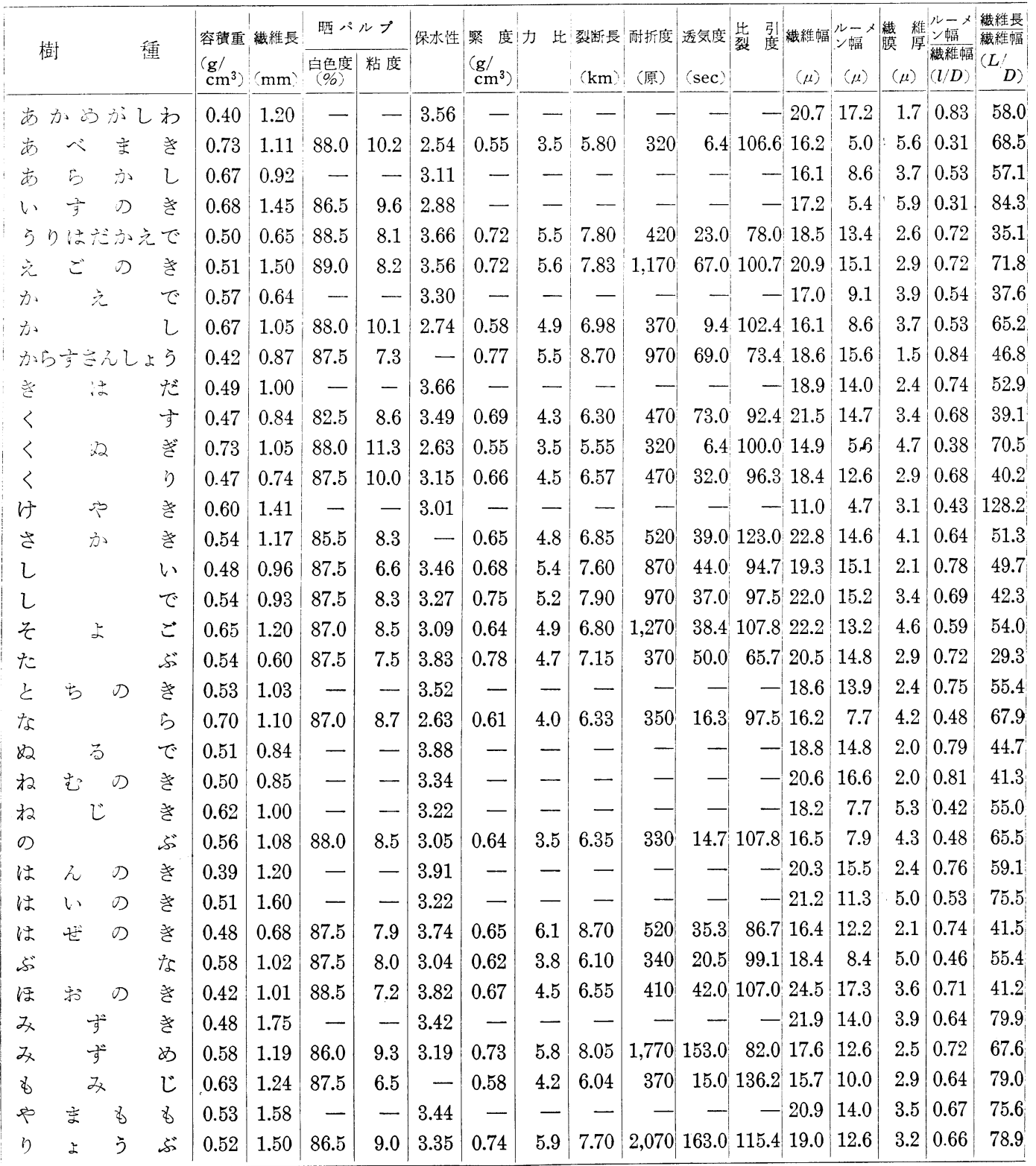

緻密で密度が大となる。反対にルーメン幅が大きく繊 維膜厚のうすい瀻維から構成された木材は容積重が低 い傾向方方ら。

$$
\begin{array}{rlrl}
\text { 南 方 材 } & \text { 日本産材 } \\
\text { 相関倸数 } r=-0.73 & r=-0.83 \\
\text { 回帰直線 } X=-0.982 Y+1.09 & X=-1.425 Y+1.40 \\
Y=-0.545 X+0.85 & Y=-0.48 X+0.84
\end{array}
$$

またこえら因子間には道管や，ある程度の柔細胞組 織によっても影響をらけるが，高い負の相関関係が得 られる。彷って大部分の木材については繊維幅に対す
るルーメン幅の比 $\bar{l} / \bar{D}$ から容積重が推定出来るとと もに, 容積重から纎維ディメンションの比 $\bar{l} / \bar{D}$ が推 定出来る。

\section{3. ルーメン幅/緎維幅 $\overline{\boldsymbol{l}} / \overline{\boldsymbol{D}}$ と保水性との関係}

水中に䀣濁した繊維は著しく水の流動性を変化させ るので懸濁した繊維の性質は，抄紙工程でのワイヤー 上における水切れや紙質滵接な影響を与兄る重要な 因子となる。すなわち水の流動性は繊維の色々な特性 によって大きく変化することは，充分理解されうるこ とで㟔るが，そのうちでも繊維の長さ，纎維の柔軟性 
ならごに可撓性は, 最も大きな要因であるといわれて いるcここで洛樹種よりホロセルロースを調製し， その保水性 ${ }^{(18)}$ と繊維の形態的特性間の関係を謂べて みた。その結果両因子間には第3図に示されるように 高い正の相関関係が得られた。

\section{日本産材}

$$
\begin{array}{ll}
\text { 相関係数 } & r=0.84 \\
\text { 回帰直線 } & X=0.355 Y-0.56 \\
& Y=1.99 X+2.09
\end{array}
$$

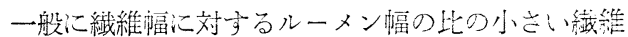
は，ルーメン幅がせまく繊維膜厚が厚い。气のたるこ のような形態構造を取っ繊維の棈断面洁，门形を呈し 硬直となる。良ってこの比方小さくなると，単䋊維間 の接触面積は漸次減少し間隌が増加する。その心水 は緎維間に保持され難くなり保水性は低下子る。一方 ルーメン幅が大さく膜厚のうすい瀻維法, 柔軟性に富

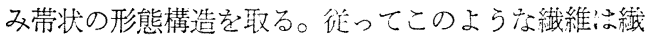
維間の接触面積は大きくなり，繊維間に保持された水 は流動し難くなる。またこの場合内腔に保持される水 の量も, 内腔の大きさにより異なり無視し雚、要因と なると考えられるが，一般汇はこの比が增すと保水性

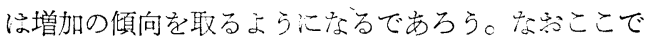
南方材についてはこれらの関係を示さなかったが，い づれも日本産材と同㥞にルーメン幅のせまい繊維膜厚 の厚い繊維は保水性が低く，この比が大きくなるに往 い高い保水性を示す傾向が認められた。竞たこ礼らの 関係を溶解用パルプのアルカリセルロースの圧搾の難 易について，形態的特性との関係を比䡆検討したが， その結果これらの特性が少なからず影響を䋇よぼすこ とを認めた。

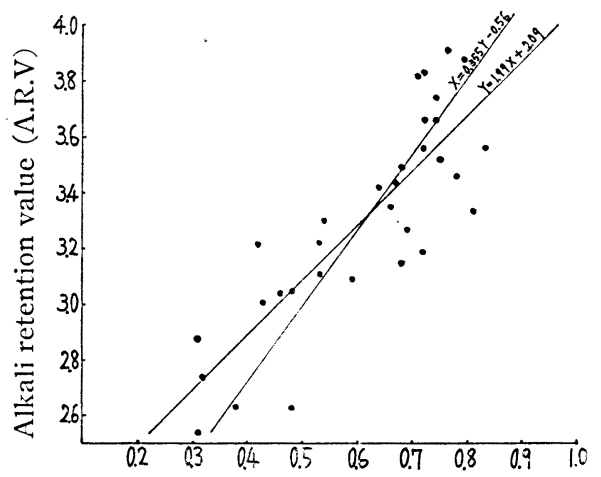

Lumen diameter/Fiber diameter $(\bar{l} / D)$

Fig. 3 Correlation between the alkali retention value of Japanese hardwoods and the ratio of lumen diameter to fiber:diameter.

\section{4、ルーメン幅/繊維幅 $\bar{l} / \bar{D}$ と緊度間の関係}

第 $4 ， 5$ 図は坪量 $60 \mathrm{~g} / \mathrm{m}^{2}$ ，濾水度 $210 \mathrm{cc}$ に和ける 手抄シートの緊度と繊維特性間の関倸を示したものて 西るc

$$
\begin{array}{cll} 
& \multicolumn{1}{c}{\text { 南 方材 }} & \text { 日本座材 } \\
\text { 相関係数 } & r=0.84 & r=0.79 \\
\text { 回帰直線 } & X=2.89 Y-1.45 & X=1.455 Y-0.34 \\
& Y=0.243 X+0.56 & Y=0.432 X+0.3 \leftarrow
\end{array}
$$

南方材ならびに日本産材ともいづれも高い正の相哭 閵係が示される。繊維幅に対するルーメン幅の比ぶ小 さい緎維は円型をなし，柔軟性が小さいので吒解性に そしく潰れ難い。そのためこのよらな纎維から作った シートは，必然的に繊維間の空陌が多く紙の密容法減 少する傾向を示すで允ろら。一方繊維幅に対するルー メン幅の比が大さい繊維は柔軟性に富又, 叮解により 潰されやすい。従ってこのような繊維から作ったシー トでは巣繊維間の接触面積が増大乙繊維間陵心減少す る。そのためシートの密度は上昇し高い緊娂のシート を形成するように次る。

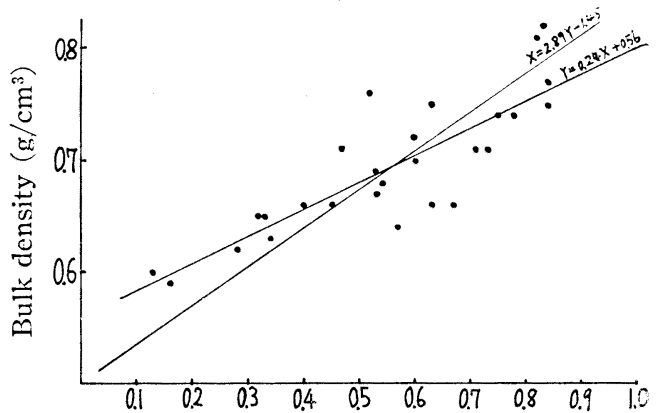

Lumen diameter/Fiber diameter $(\bar{l} / \bar{D})$

Fig. 4 Correlation between the buik density of tropical hardwoods and the ratio of lumen diameter to fiber diameter.

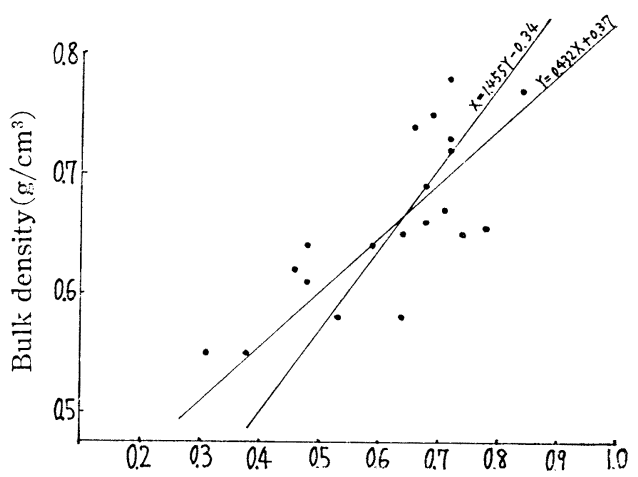

Lumen diameter/Fiber diameter $(\bar{l} / D)$

Fig. 5 Correlation between the bulk density of Japanese hardwoods and the ratio of lumen diameter to fiber diameter. 


守屋正 夫

\section{5.ルーメン幅/繊維幅 $\bar{l} / \overline{\boldsymbol{D}}$ 之剛度間の関係}

日本産材の纎維ディメンションと剛度間の関係につ いては省略したが，南方材について関係を調らべてみ ると高い負の相関関係が示される。（第 6 図）

$$
\text { 南方 材 }
$$

相関係数 $r=-0.78$

回帰直線 $X=-2.2 Y+2.22$

$$
Y=-0.28 X+0.91
$$

すなわち纎維幅に詨するルーメン幅の比が小さい円 型の繊維は, 繊維の内外層の圧縮や伸長に対する能力 が大さく剛度が高い。一方ルーメン幅が大くく繊維膜 厚がうすい繊維は柔軟性が大きいため，圧縮や伸長に 対する能力が低下する。

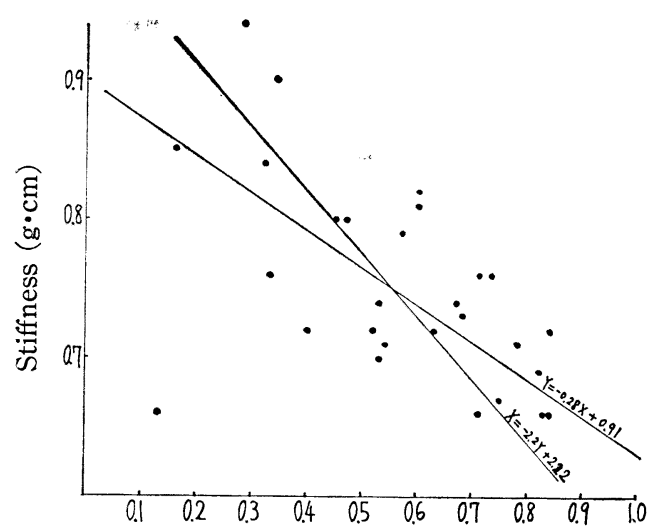

Lumen diameter/Fiber diameter $(\bar{l} / D)$

Fig. 6 Correlation between the stiffness of tropical hardwoods and the ratio of lumen diameter to fiber diameter.

\section{6. ルーメン幅/繊維幅 $\overline{\boldsymbol{l}} / \overline{\boldsymbol{D}}$ と力比間の関係}

第 $7 ， 8$ 図には南方材ならびに日本産材の繊維ディ メンションと力比との関係を示した。

$$
\begin{array}{lll} 
& \multicolumn{1}{c}{\text { 南 方材 }} & \multicolumn{1}{c}{\text { 日本麾材 }} \\
\text { 相関係数 } & r=0.85 & r=0.80 \\
\text { 回㷌直線 } & X=0.19 Y-0.25 & X=0.123 Y+0.047 \\
& Y=3.80 X+2.1 & Y=5.16 X+1.50
\end{array}
$$

いづれも高い正の相関関係が示される。従ってこの 比が増減すると繊維の柔軟性やつぶれやすさが変り, 繊維間の結合面積やシートの地合などに影響を与え， 紙の破裂強度が支配されるものと考えられる。そのた めこの比が大きい繊維から作られたシートは，その大 部分にわたって破壊の応力を分散させることのできる 結合が与えられ，紙は望ましい紙力を得るであろう。

一方この比が小さくなると紙の強度は, 漸次低下の 傾向をたどる。従って化学的成分の変動は無視するこ とが出来ないが，紙の引張り強さや伸びに対しては緎
維特性の比が強く関倸しているといえよう。

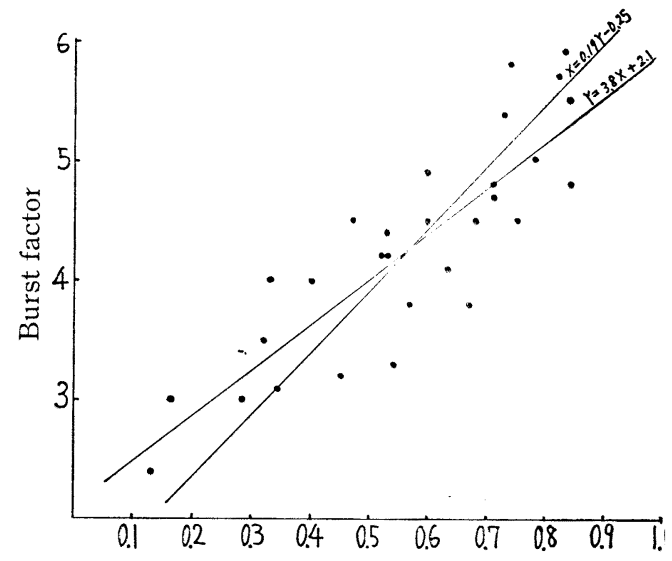

Lumen diameter/Fiber diameter $(\bar{l} / D)$

Fig. 7 Correlation between the burst factor of tropical hardwoods and the ratio of lumen diameter to fiber diameter.

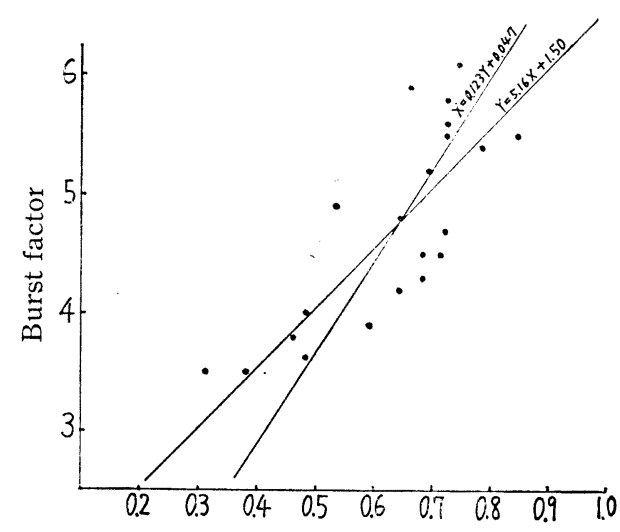

Lumen diameter/Fiber diameter $(\bar{l} / D)$

Fig. 8 Correlation between the burst factor of Japanese hardwoods and the ratio of lumen diameter to fiber diameter.

\section{7、 ルーメン幅/繊維幅 $\bar{l} / \bar{D}$ 之裂断長間の関係}

かっては紙の引張り強さ之破裂度は他の主要な強度

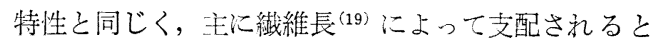
一般に考えられていた。しかし今日ではこれら紙の性 質は，繊維の柔軟性 ${ }^{(12)}$ とシートの厚さ ${ }^{(20)}$ に依存して いることが明らかてされて㧍り，繊維間結合の量と質 が弓張りに影響する最も重要な因子であると考えられ ている。

第 9,10図に浊南方材ならびに日本産材の繊維ディ メンションの比と裂断長との関係を示した。いづれの 場合にもこれら因子間には高い正の相関関係が示され 
๖。

$$
\begin{array}{lll} 
& \multicolumn{1}{c}{\text { 南 方而材 }} & \multicolumn{1}{c}{\text { 日本産材 }} \\
\text { 相関係数 } & r=0.80 & r=0.79 \\
\text { 回帰直線 } & X=0.153 Y-0.41 & X=0.109 Y-0.13 \\
& Y=4.163 X+4.05 & Y=5.737 X+3.41
\end{array}
$$

またこれらの関係泣前述の力比の場合と同様に，繊 維のディメンション比が大きくなるに従って紙の強度 尚向上する傾向が認められ, 瀻維ディメンションの比 が，こ机らの因子之関倸のあることを示している。

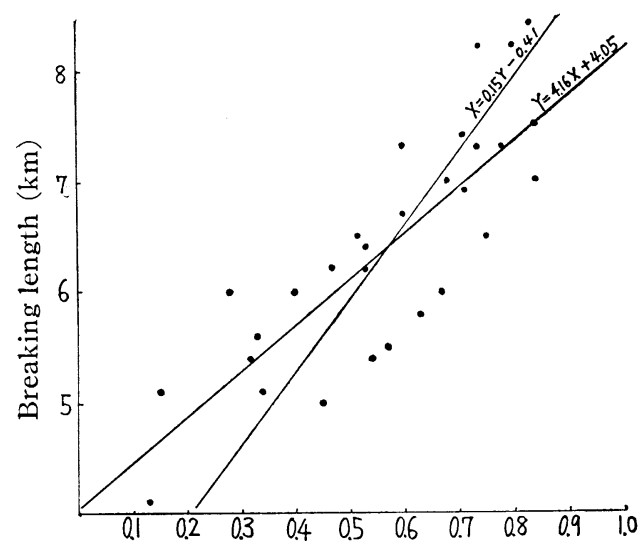

Lumen diameter/Fiber.diameter $(\bar{l} / D)$

Fig. 9 Correlation between the breaking length of tropical hardwoods and the ratio of lumen diameter to fiber diameter.

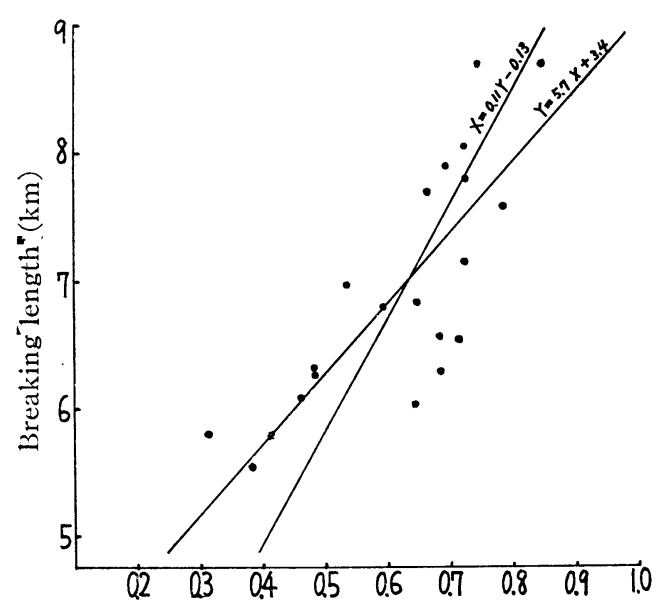

Lumen diameter/Fiber diameter $(\bar{l} / D)$

Fig. 10 Correlation between the breaking length of Japanese hardwoods and the ratio of lumen diameter to fiber diameter.

\section{8. ルーメン幅/繊維幅 $\bar{l} / \bar{D}$ 之耐折度間の関係}

第 11,12 図には南方材ならびに日本産材の繊維ディ メンション比と耐折度との関係を示した。

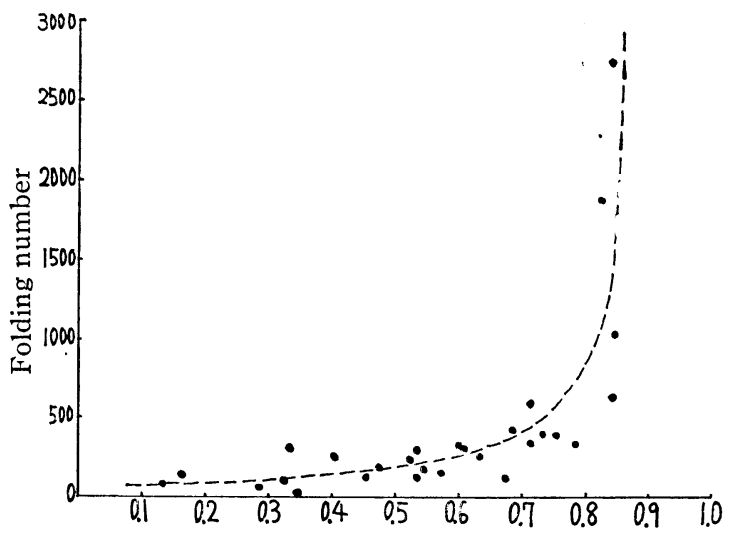

Lumen diameter/Fiber diameter $(\bar{l} / D)$

Fig. 11 Correlation between the folding number of tropical hardwoods and the ratio of lumen diameter to fiber diameter.

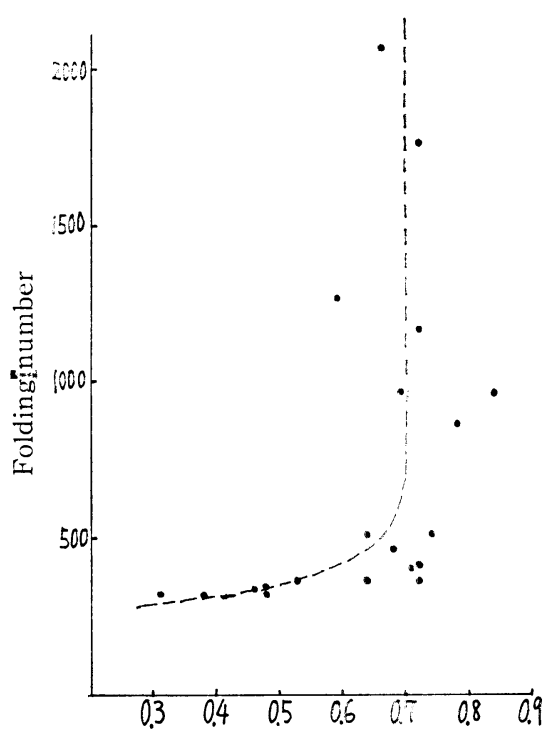

Lumen diameter/Fiber diameter $(\bar{l} / D)$

Fig. 12 Correlation between the folding number of Japanese hardwoods and the ratio of lumen diameter to fiber diameter.

$$
\text { 南方材日本産材 }
$$

相関倸数 $r=0.53 \quad r=0.40$

南方材ならびに日本産材ともかなりの正の相関関倸 が示される。しかしここでこ礼因子間の関係は, 前 述の関連性とはやや異なる傾向が示さ机る。すなわち 瀻維幅汇対するルーメン幅の比が一定の值以上になる と，耐折度は急比上昇する。乞してこの上昇の起る点 注相対的汇平均繊維長の長い南方材の方が, 日本産材 よりやや大きい比の所で起る。従って紙の耐折度恃 Clark ${ }^{(21)}$ ら斥述べているように, 纎維の膜厚, 秋材率, 
維維の剛度，繊維長，繊維の柔軟性など，多くの因子 の相互作用により影響を受汀るものと考兄られ，直接 的な関倸は充分に示し得ない。

\section{9. ルーメン幅/繊維幅 $\overline{\boldsymbol{l}} / \overline{\boldsymbol{D}}$ と透気度間の関係}

第 13,14 図には南方材ならごに日本産材の繊維ディ メンション比と透氮度間の関係を示した。これら因子 間にはかなりの正の相関関係が示される。しかしこれ

$$
\text { 南方材日本産枱 }
$$$$
\text { 相関係数 } r=0.49 \quad r=0.49
$$

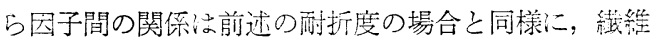
ディメンション比が一定值以上になると, 透気宗はこ の比に影響されることなく急に上昇する。嗞って䌊の 透気抵抗は耐折度々同様に多くの形態的因子の影暃を

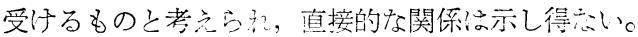

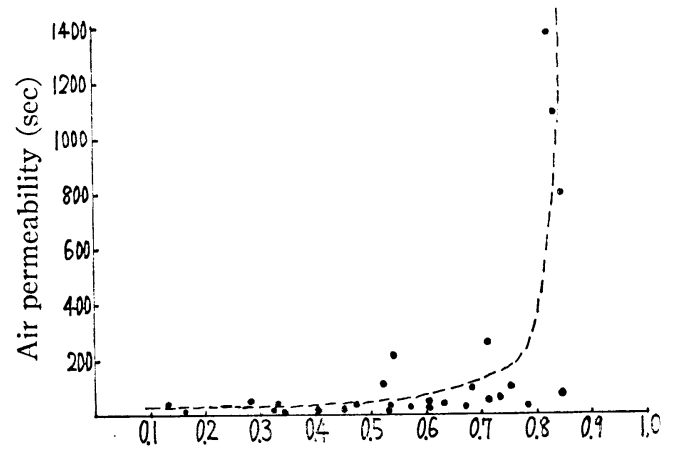

Lumen diameter/Fiber diameter $(\bar{l} / D)$

Fig. 13 Correlation between the air permeability of tropical hardwoods and the ratio of lumen diameter to fiber diameter.

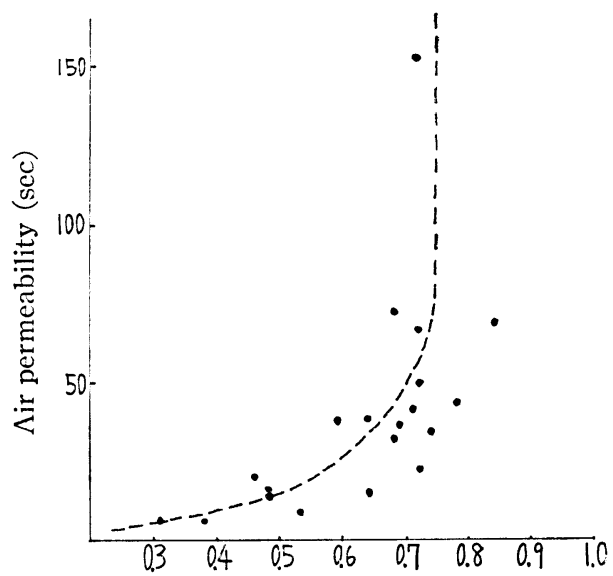

Lumen diameter/Fiber diameter $(\bar{l} / D)$

Fig. 14 Correlation between the air permeability of Japanese hardwoods and the ratio of lumen diameter to fiber diameter.

10. 繊維長/繊維幅 $\bar{L} / \bar{D}$ と比引裂き度間の関係

紙の引裂き強度は繊維長, 繊維の数, 繊維間の結合 面積，あるいは䋐維幅に対する繊維長の比などの要因 が関与するといわれている(22 23)。南方材ならでに日

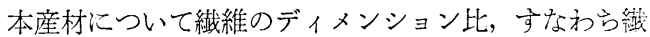
維幅に対するルーメン幅の比と引裂き強度との関保を 調らべたが，前述のような紙質間との関連性は得られ なかった。そのため引裂さ強度には特に繊維ディメン ション組み合せ比を変更し，繊維幅に対する繊維長の 比を取り，これら因子間の相関関係を求めた。第 15 , 16 図にはこれら因子閣の関係を示した。

南方材

楦阔系数 $r=0.74$

$$
\begin{array}{ll}
X=0.909 Y-16.61 & X=0.568 Y-0.917 \\
Y=0.60 X+61.3 & Y=0.64 X+63.33
\end{array}
$$

西者の因子間にはいづれもかなり高い正の相関関倸 が示される。すなうち䋐維幅に対する繊維長の比が大

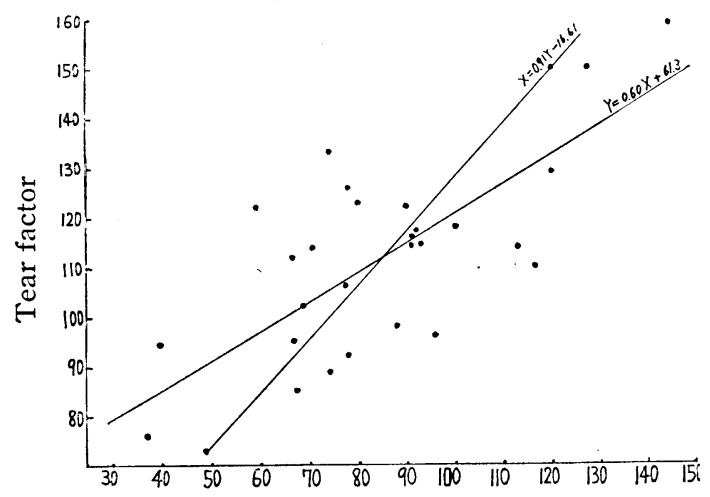

Fiber length/Fiber diameter $(\bar{L} / D)$

Fig. 15 Correlation between the tear factor of tropical hardwoods and the ratio of fiber length to fiber diameter.

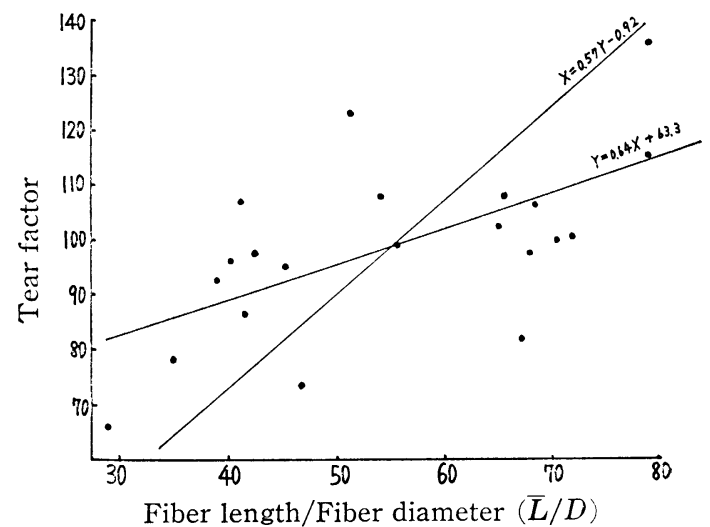

Fig. 16 Correlation between the tear factor of Japanese hardwoods and the ratio of fiber length to fiber diameter. 
きくなるに從い引裂き強度は上昇する。一方この比が 小さくなると强度は低下する。従って悢の引裂き強度 はこの比の增减によってかなりの影響を受け関漣性が 深い。

\section{1、繊維特性之原木の容積重ならびに紙質の関係}

前述のこれら一連の研究結果は南方産広葉橱ならび に日本産広葉樹念含㝐範囲の原木の容積重, 壳るい はこれらを原料こして造られたクラフトパルプの緍質

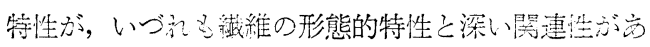
ることを示している。すなわらこれらの閴䌽を要約し て示すと次のミうな算係が得られる。

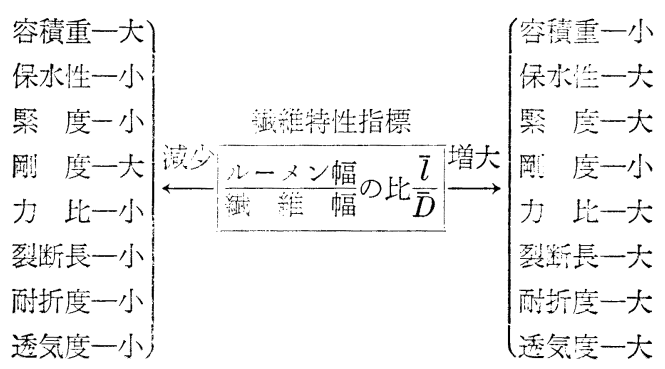

瀻維特性指標

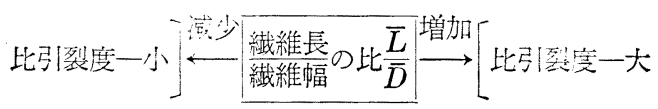

すなわち原太の容積重や紙の性質は非常に多くの因 子によって影響受けるが，これら多くの要因のらち， 織維幅に対するルーメン幅の比, あるいは瀻維幅に対 する繊維長の坛法，こ就らの諸性質との関連性を決定 するのに非常に重要学星のであることが判炽した。こ こで容積重は踄維幅に対するルーメン幅の比に直接関

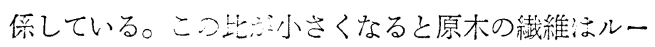
メン幅が小さく旗厚が厚くなる。從って単位容積 当りの填充密赛:犬之主り容積重は増加方る。パルプ の保水性は瀻縒幅に二対するルーメン幅の比によって決 定される。この讫潧すと瀻維はルーメン幅が大きく 膜厚がうすく的柔軟性となる, 従って繊維間の接触 面積が増加し綨維間湻持された水の離脱が抑制され る。またルーメン䏽中に保持された水の量も影響をお よぼし重要でちるように考光られる。紙の緊度は繊維 幅に対するルーメン幅の比強く相関している。この

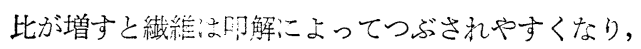
瀻維間の結合面、㣱引増加し地合が良好となり緊度は高 くなる。

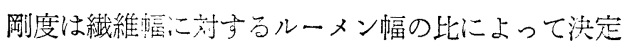
される。この咕う增す之繊維は柔軟性が大きくなり, 圧縮や伸長に対する能力が低下し紙の剛度は小さくな

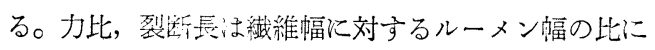
高度に相関している。この比が増すと䋐維は叮解によ
ってつぶれやすくなる。徒って䄳の構成単位である単 繊維間の結合面積が増加し紙力は向上する。耐折度, 透気度に関しては多くの因子依存していることが見 出され明確な結論は下せ得ないが，纎維幅汇対するル 一メン幅の比は重要な指標であるように思われる。比 引裂き度は繊維幅に対する繊維長の比によって充分説 明できる。すなわち引裂き強度は繊維の絡及合い性が 大きく影響している。従ってこの比が増すと紙の引裂 強度は増加するようになる。以上これらの結果渽維 の形態的特性が，原木の容積重や紙の性質汇予想以上 に影響することを示している。そして重要性を示す瀻 維の形態的特性法, 各䋐維ディメンション単独の場合 よりもディメンションの組み合せにより表された特性 比の方が，上り関連性が深いことを示している。従っ てこれらの繊維特性のデータから原木の容積重, ある いは紙の性質の予想，または紙質を改善するための手 掛りをうることが可能となるう。またこれらの検討路 さらにパルプの吒解性, 伸縮性, 光学的性質, 製造法 が，アルカリまたは酸性蒸解法によるかの相違, ある いは針葉樹やその他の植物性原料緎維沉ついても，さ らに注意をむけるべきであり，検討する必要があるう。

\section{IV 総括}

南方産広葉樹ならびに日本産広葉樹を対象沉て緎 維の形態的特性と木材の容積重パルプの保水性およで 紙葉の強度的特性間の関倸について検討を行なった。 その結果大抵の樹種の場合に次のような関連性が得ら れる。

1. 繊維のディメンション比特に繊維幅に対するル 一メン幅の比は, 木材の容積重, パルプの保水性, 紙 の緊度, 剛度, 力比, 裂断長, 耐折度, 透気度などの 性質間住，相関関倸が成立する。

2. 繊維幅に対する䋊維長の比は, 紙の比引裂き度 との間に相関関係が示される。

3. 従ってこれらの繊維ディメンション比を指標に し, パルプ用原木の品質の評価ならびに紙葉の性質を 改善するための手脚りを得ることが可能となるう。

\section{引 用 文 献}

(1) Tappi Forest Biology Committe Tappi 43 $40 \mathrm{~A}(1960)$

(2) R. Peteri, Tappi 35157 (1952)

(3) 今村, 㵶学誌 911 (1952)

(4) W.F. Holzer \& H. F. Lewis, Tappi $33110(19$ $50)$

(5) M. W. Bray \& C. F. Curran, Paper Trade J. $105(20) 39$ (1937)

(6) C.F. Curran, Paper Trade J. 106(23) 1(1938)

(7) G. H. Chidester \& J. N. McGovern, Paper

Trade J. 107 (13) 24 (1938)

( 8 ) E. Hägglund "wood chemistry" 
(9) R. O. H. Runkel, Das Papier 3476 (1949)

(10) A. T. Watson \& I. G. Hodder APPITA Proc. 6290 (1954)

(11) J. M. Dinwoodie, Tappi 48440 (1965)

(12) F. N. Tamolong \& F. F. Wangaard, Tappi 44 201 (1961)

(13) F. F. Wangaard, Tappi 45548 (1962)

(14) A. Mottet, Svensk PT 66521 (1963)

(15) J. M. Dinwoodie, Tappi 4957 (1966)

(16) F. F. Wangaard, R. M. Kellogg \& A. W.

Brinkley J. R. Tappi 49263 (1966)

(17) 会画貞助：南洋材の知識

須藤彰司：南洋材の知識

農林省林業試験場木材部偏：洋材 1000 種

(18) T. Hopner, G. Jayme \& J. Vlrich, Das Papier 9476 (1955)

(19) W. F. Holzer P.P.M.C. 51163 (1950)

(20) B. Malmberg, Svensk PT 6769 (1964)
(21) J.d.A. Clark, Paper Trade J.115(26) 36(1942)

(22) J. Casey "Pulp and Paper Vol. II"

(23) 户田，木島 紙パ技誌 15255 (1961)

$$
\text { (原稿受付 昭 41.10.1:) }
$$

12th EUCEPA-Conference on Board \& Solid Fiber Board Technology \& Technique 会期・場所：1968 年 4 月 22-26 日 Berlin

講 演主題：貼り合わせ結合力，こわさ，筋押し，絶 縁耐力, 長網および丸網結合抄紙機, ク 一チ拉よびプレス光沢付忷カレンダーが 河, 仕上げ工程(顔料怙よびプラスチック 塗工，張り合わせ，二不引き，，原料調 整とその傾向, 加工 (需要, 標準, テス 卜法）などの外に Inverform その他形 成機沉よる体験円卓討議。(EUCEPA= Comité Européen de Liaison Pour la Cellulose et le Papier) (䈍\#)

\section{特 許 公 報}

\begin{tabular}{|c|c|c|c|c|}
\hline 公告年月日 & 公告番号 & 出願番号 & 発 明 の 名 称 & 願 \\
\hline 昭41.12. 5 & 昭41-20838 & 昭38-51421 & 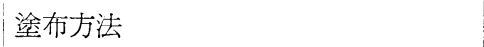 & 富士写真フイルム株式全社 \\
\hline 12.19 & 21725 & $39-15215$ & 携帯用木材皮剝機 & 新ダイワ工業株式会社 \\
\hline \multirow[t]{8}{*}{ 42. 1.17} & $42-801$ & $37-58903$ & 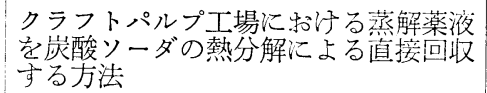 & 王子製紙株式今社 \\
\hline & 802 & $38-12375$ & $\begin{array}{l}\text { マグネシウムベースサルファイト蒸解 } \\
\text { 廃液よりの薬品とリグニンの回収法 }\end{array}$ & 新日本化学工蛘株式会社 \\
\hline & 803 & $39-72028$ & 繊維含有パルプ洗浄容器 & アクチボラゲット．カミル \\
\hline & 804 & $36-7106$ & 製紙用サイズ剂 & 大日本インキ化学工羑株式会社 \\
\hline & 805 & $38-23982$ & 塗膜組成物 & イーストマン・コダック, カンバ=ー \\
\hline & 806 & $36-3677$ & $\begin{array}{l}\text { エマルジョン型の石油樹脂サイズ剂を } \\
\text { 用いて無サイズ紙に表面サイズを施こ } \\
\text { 寸方法 }\end{array}$ & 王子製紙株式会社 \\
\hline & 807 & $37-31217$ & 電気絶縁材料の製造法 & 占河電気工業株式会社 \\
\hline & 808 & $37-31710$ & 電気絶縁材料の製造法 & 古河電気工業株式会社 \\
\hline 1.19 & 1035 & $38-55587$ & 防水剤の製造方法 & 積水化学工業株式会社 \\
\hline \multirow[t]{2}{*}{1.20} & 1153 & $39-10738$ & 空気濾過器用濾紙製造法 & 池田五郎 \\
\hline & 1154 & $39-20046$ & 濾紙の製造方法 & 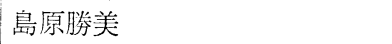 \\
\hline \multirow[t]{11}{*}{1.23} & 1321 & $38-45141$ & 化学物質と熱の回収装置 & バブコック, アント, ウイルニックス \\
\hline & 1322 & $37-55180$ & 製紙用化学パルプの製造法 & 山陽パルプ株式会社 \\
\hline & 1323 & $38-29000$ & 古紙からインキを抜く方法 & 小坂玉二 \\
\hline & 1324 & $37-2985$ & 製紙サイズ用組成物 & 星光化学工業株式会社 \\
\hline & 1325 & $38-16053$ & 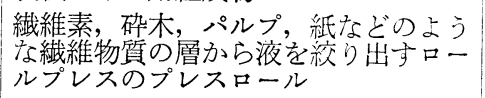 & クラウス, マッフフイ, イムリアル \\
\hline & 1326 & $37-5406$ & 整流ロール支持装置 & ベロイト・コーポレーション \\
\hline & 1327 & $38-16055$ & 脱水装置 & クラウス, マッファイ, イムベリアル \\
\hline & 1328 & $39-22703$ & 分割プレス装置 & ベロイト・コーポレーション \\
\hline & 1329 & $35-41681$ & 塗被紙の製造法 & 三菱製紙株式会社 \\
\hline & 1330 & $37-26681$ & 強サイズ紙の製造法 & 星光化学工業株式会社 \\
\hline & 1331 & $38-45308$ & 有機溶剤を用いる低密度紙製造法 & 本州製紙株式会社: \\
\hline
\end{tabular}

\section{実 用 新 案 公 報}

\begin{tabular}{|l|l|l|lll||c|c|}
\hline 公告年月日 & 公告番号 & 出願番号 & 考 & 案 & の 名 称 & 出 願 & 人 \\
\hline 昭41. 1.25 & 昭42- 1278 & 昭41-83128 & 加熱装置 & & & & 三菱重工業株式会社
\end{tabular}

